\title{
Caring for newborns in the presence of their parents: the experience of nurses in the neonatal intensive care unit
}

\author{
Miriam Aparecida Barbosa Merighi ${ }^{1}$ \\ Maria Cristina Pinto de Jesus ${ }^{2}$ \\ Karine Ribeiro Santin ${ }^{3}$ \\ Deíse Moura de Oliveira ${ }^{4}$
}

The nurse has a key role in involving parents in the care of newborns in the neonatal intensive care unit. The aim of this study was to comprehend how the nurses experience the care provided to newborns in the presence of the parents. This is a qualitative study using social phenomenology, with the participation of seven nurses, interviewed between January and February 2009. The nurses perceived the needs of parents; had positive expectations regarding the care provided and acknowledge themselves to be the link between them, helping them to live with the hospitalized child. However, in emergencies, the nurses had difficulties in caring for the neonate in the presence of the parents. The nurses positively evaluated the presence of parents in the neonatal intensive care unit, involving them permanently in the care of the newborn. The study evokes the emergence of a care context (nurse/neonate/parents) that precedes the proximity between the subjects and the demands presented by them.

Descriptors: Nursing; Infant, Newborn; Parent-Child Relations; Intensive Care, Neonatal; Qualitative Research.

\footnotetext{
${ }^{1}$ RN, Ph.D. in Nursing, Full Professor, Escola de Enfermagem, Universidade de São Paulo, SP, Brazil. E-mail: merighi@usp.br.

${ }^{2}$ RN, Ph.D. in Nursing, Associate Professor, Faculdade de Enfermagem, Universidade Federal de Juiz de Fora, MG, Brazil. E-mail: cristina.pinto@acessa.com.

${ }^{3}$ Undergraduate student in Nursing, Escola de Enfermagem, Universidade de São Paulo, SP, Brazil. Scholarship holder of the Scientific Initiation Program at the Conselho Nacional de Desenvolvimento Científico e Tecnológico (CNPq). E-mail: kasantin@gmail.com.

${ }^{4}$ RN, Doctoral student in Nursing, Escola de Enfermagem, Universidade de São Paulo, SP, Brazil. E-mail: deisemoura@hotmail.com.
}

Corresponding Author: Deise Moura de Oliveira Rua Nestor Vasconcelos, 55 Bairro: Quintas da Avenida CEP: 36046-630, Juiz de Fora, MG, Brasil E-mail: deisemoura@hotmail.com 


\section{Cuidar do recém-nascido na presença de seus pais: vivência de enfermeiras em unidade de cuidado intensivo neonatal}

A enfermeira tem papel fundamental no envolvimento dos pais no cuidado ao recémnascido, na unidade de terapia intensiva neonatal. O objetivo deste estudo foi compreender como as enfermeiras vivenciam o cuidado prestado ao recém-nascido, na presença dos pais. Usou-se a pesquisa qualitativa com abordagem da fenomenologia social, como metodologia. Participaram deste estudo sete enfermeiras, entrevistadas no período de janeiro e fevereiro de 2009. Como resultado tem-se que a enfermeira percebe as necessidades dos pais; tem expectativas positivas em relação ao cuidado realizado e reconhece ser o elo entre eles, ajudando-os a conviver com o filho internado. Contudo, em situações de emergência, tem dificuldades para cuidar do neonato na presença dos pais. Pode-se concluir que a enfermeira avalia positivamente a presença dos pais na unidade de terapia intensiva neonatal, envolvendo-os permanentemente no cuidado ao recém-nascido. O estudo evoca a emergência de um contexto de cuidado (enfermeira/ neonato/seus pais) que precede a aproximação entre os sujeitos e as demandas por eles apresentadas.

Descritores: Enfermagem; Recém-Nascido; Relações Pais-Filho; Terapia Intensiva Neonatal; Pesquisa Qualitativa.

\section{Cuidar del recién nacido en la presencia de sus padres: vivencia de enfermeras en unidad de cuidado intensivo neonatal}

La enfermera tiene un papel fundamental en el envolvimiento de los padres en el cuidado al recién nacido en la unidad de terapia intensiva neonatal. El objetivo del estudio fue comprender como las enfermeras experimentan el cuidado prestado al recién nacido en la presencia de los padres. Se trata de una investigación cualitativa con abordaje de la fenomenología social; tuvo la participación de siete enfermeras, entrevistadas en los meses de enero y febrero de 2009. Se encontró que la enfermera percibe las necesidades de los padres, tiene expectativas positivas en relación al cuidado realizado y reconoce ser el eslabón entre ellos, ayudándolos a convivir con el hijo internado. Sin embargo, en situaciones de emergencia, tiene dificultades en cuidar al neonato en la presencia de los padres. Concluimos que la enfermera evalúa positivamente la presencia de los padres en la unidad de terapia intensiva neonatal, envolviéndolos permanentemente en el cuidado del recién nacido. El estudio evoca la emergencia de un contexto de cuidado (enfermera/ neonato/sus padres) que precede a la aproximación entre los sujetos y las demandas por ellos presentadas.

Descriptores: Enfermería; Recién Nacido; Relaciones Padres-Hijo; Cuidado Intensivo Neonatal; Investigación Cualitativa.

\section{Introduction}

In the Neonatal Intensive Care Unit (NICU), the focus of the care has been the biological aspects, however this issue is being discussed between health professionals in order to transform this reality, expanding and focusing the care not only on the disease of the newborn, but also on the social, emotional and psychological dimensions of the family ${ }^{(1)}$. Nurses assume an important role in the context of the NICU, because they develop collaborative work with the physician in the strategies and decisions, provide direct care to the newborn and give support to the family ${ }^{(2)}$. However, there are many difficulties that nurses face regarding 
the interaction, especially in relation to the needs of the parents of the newborn to expose their feelings. Because of the characteristics of these sites, the nurses and other health professionals who carry out their activities there are almost always intimately involved in high-complexity procedures. In this sense, interpersonal relationships can be compromised(3). The nurse has a fundamental role concerning the involvement of the parents in the activities of the NICU, particularly regarding guidance in the first visit. This professional should provide support in order to reduce the anxiety and fear that the parents of the newborn feel, providing minimum conditions of comfort, trying to respond to concerns and providing information on the health of the newborn, the treatment and the equipment used ${ }^{(4)}$.

In the family circle, there is no stage that causes more profound change that the birth of a child and with the birth of an at risk neonate the family is faced with a challenging and exhausting experience ${ }^{(1)}$. At this time, the parents of the babies undergo a unique and difficult experience, with it being the nurse's responsibility to involve them in the care, supporting them and sharing their doubts, fears and uncertainties and, consequently, generating warmth and security. It is necessary that the nurse use an approach centered on the child and the family, from a holistic perspective, identifying the family of the newborn as primarily responsible for the care of its members. Therefore, they should consider the problems, needs, interests, resources, capabilities and expectations of all of the family in the healthcare of hospitalized children(5). Communication, knowledge and the comprehension of the family context, inserted into a physical, social and cultural situation, should be prioritized. Technical and scientific competence is not enough to address this integral comprehension of the human being. Nurses also need to improve their knowledge and skill in interpersonal relationships, as the art of caring is to find a way to let the sick person express their needs. Thus, caregivers should be able to listen to people suffering from disease and respond to their health and well-being needs as widely as possible ${ }^{(6)}$. Given this premise, in the act of caring for people and through observations of the quotidian in the NICU which generate reflections about the care provided by nurses in the presence of the parents of newborns the following questions arose: what is it like for nurses attending newborns hospitalized in the NICU when the parents are present? What do the nurses consider when caring for the newborn when the parents are present?

Although several studies have addressed the participation of the parents of newborn babies hospitalized in the NICU(4,7-12), the present study is based on the fact that, of the literature investigated, few studies emphasize the themes that seek to comprehend this experience from the perspective of the nurse. Therefore, this study aimed to comprehend how nurses experience the care provided in the NICU faced with the presence of the parents of the newborns. Considering that, in a NICU, the presence of the parents is configured in a matricial anchor of care, it is fundamental to comprehend how the nurses of this practice scenario experience their care actions faced with the presence of parents, who also have needs that must be included in the planning and execution of the actions directed towards the neonate.

\section{Theoretical methodological framework}

This study uses the comprehensive approach of human phenomena from a concrete experience, experienced in the quotidian world. It is guided by social phenomenology, which allows a better comprehension of the experience of the nurse who takes care of the newborn in the presence of the parents, with this experience taken not only as unique and singular, but also endowed with a social meaning confined to the context of care which emanates from the nurse/newborn/parents relationship. Social phenomenology, such as advocated by Alfred Schütz, aims to comprehend the world with others in their intersubjective meaning. It proposes the analysis of social relations, viewed as mutual relationships that involve people. Social phenomenology is structured on the meanings of the intersubjective experience of the social relationship and focuses on the treatment of social actions that have a contextualized meaning and configure a social sense ${ }^{(13)}$. The intersubjective social relationship is essentially a form of communicative expression. To capture the subjective point of view, it is necessary to refer to the interpretation that the subjects attribute to the action in terms of projects, available means, motives and meanings ${ }^{(13)}$.

Social action is behavior directed toward achieving a particular purpose, and this action can only be interpreted by the subjectivity of the person, as only they can define their action project, their social performance. In this sense, comprehending the social focuses on social behavior in relation to the reasons, on the intentions that guide action and on their meanings from the perspective of the author of the action(13). Reason refers to a state of affairs, the objective to be achieved through the action. "Reason why" refers to 
past experiences (objective category), accessible to the researcher. The context of the meaning of the true "reason why" is always an explanation that justifies a given event. "Reason for" is the guidance for the future action, thus a context of meaning that is constructed regarding the context of experiences available at the time of the projection (subjective category). We can capture the experience of a subject if we find their "reason for" - the act anticipated, imagined, subjective meaning of the action(13). The subjective meaning of the action allows the construction of the experienced type - an expression of a structure lived in the social dimension, a characteristic of a social group, a concept expressed by intelligence, that's experienced nature is invariant. The experienced type is reached through the analysis of social relationships ${ }^{(13)}$.

The NICU, site of the study, is part of a teaching hospital in the city of São Paulo. Nurses who worked in the NICU of this institution, in the care of newborns, in the presence of their parents were included in the study. Age, time taken to achieve qualification and duration of practice in this area were not considered, because the study sought the lived experience. Interviews were conducted with seven nurses from different shifts, aged between 24 and 43 years. Four had performed an improvement/specialization course in the area; three had worked in the NICU for between ten and 15 years, two between one to nine years and two for less than one year. The number of participants was not predetermined and was defined by the moment at which the statements unveiled the phenomenon under investigation, the inquiries were answered and the aims achieved. Data collection took place between January and February 2009, through semi-structured interviews, with the following guiding questions: what is it like for you, to care for the newborn hospitalized in the NICU, when the parents are present? What do you consider when you care for the newborn and the parents are present?

The discourses were identified with the letter $D$, followed by the numbers 1 to 7 sequentially. The nurses were contacted at the hospital and the interviews were conducted on the premises, in a place and at a time suitable for the professionals. For data analysis, the models suggested by scholars of the social phenomenology of Alfred Schütz were used $(7,14)$ : transcription of interviews; reading of the discourses of the nurses, aiming to apprehend the motivated experience of the participant subjects; rereading of the transcripts, identifying specific categories, i.e. phrases of effect that express aspects significant in the comprehension and experience of the "motives for" and the "reasons why"; grouping of units of meaning extracted from the discourses and representing the convergence of content of the reports that compose the categories; the establishment of the meanings of the experiences typical of the discourses, to obtain the typology experienced; comprehensive analysis of the grouping of meanings. The following categories emerged from the analysis: "recognizing the needs of the parents", "feeling difficulty in an emergency situation", "being the link in the proximity of children and parents". All the procedures for performing the study followed the standards required by Resolution 196/96, of the National Health Council(15) and the research project was approved by the Research Ethics Committee of the Hospital, the site of the study (Process No. 846/08 CEP/ HU-USP).

\section{Results and Discussion}

Following the guiding questions of this study, we tried to hold attentively to what was commonly presented, that is, seeking the invariants of the "reasons for" and of the "reasons why" in the interviews, identifying the convergences of the feelings and desires of the nurses in the care actions.

\section{Category: Recognizing the needs of the parents (reasons why)}

The nurses recognized the need for care for the parents and, thus, perceived the importance of guidance regarding the procedures and the health status of the child, valuing their presence, seeing them as participants and not as spectators:

[...] for them the first moment they arrive in the ICU, daily, they want to know who is taking care of the baby, they have a lot of anxiety about this and I realize that, depending on who the professional is and the bond they have with this professional, they become less anxious (D6).

The act of caring performed by the nurse is not only emotion, concern and attitude, it is wider, complex and requires concrete actions in the humanistic, social, ethical, biological and spiritual spheres, especially when providing care inside a NICU, involving not only the professional, but also the parents of the newborn ${ }^{(16)}$. In the world of common sense, the actors occupy the scenario of the reality of quotidian life, not as a private world, but shared with other people from the beginning: an intersubjective world(13). In this scenario, nurses, parents and at risk newborns experience the action, the situation and the interpretation of their 
actions, equipped with perspectives, each with their baggage of knowledge and biographical situation. The nurse clarifies the doubts of the parents and this action originates in the consciousness of this professional, is voluntary and is projected toward the purpose of reducing anxiety, facilitating the parents being with the child so they can feel confident and integrated into the role of father and mother in the recuperation of the child:

[...] they walk in, look, and usually gets very worried. When they are leaving, if I am present, I try to stay beside them. Did you see the baby? What will you call him? What are the questions that the parent has in relation to all this? You end up forming a bond with this family [... ] (D6).

Ways of communicating and interacting with the families of infants hospitalized in Intensive Care must be established, promoting the participation of the parents in the care, guiding and encouraging them to handle their children. With this approach, a care process is constructed, preserving the uniqueness and individuality of the child and its parents ${ }^{(16-17)}$. As caring is essential for the humanization of the assistance, affection, contact with significant people, safety, responsibility, exchange and growth must be brought to the quotidian of the work. It was noticed that, to account for the participation of parents in the NICU, it was necessary to rethink not only their own interpersonal relationships in this context, but also the importance of the integral care. In this sense, the typical action of nurses in relation to the parents of newborns hospitalized in the Neonatal Intensive Care Unit is shown in the perspective of interaction and family participation in the care of the child ${ }^{(18-19)}$. Reciprocity of perspectives between professional and family is perceived when the nurse cares with the aim of meeting the integral needs of not only the newborns but also of their parents:

[...] I know this sadness, this difficulty [...] it is where, in the first visits, I try to rescue [...], I call the psychologist, often the social worker is also near, the physicians, nurses in order to give full support to this mother (D1).

The care received, the interpersonal relationship between nurses and parents, the fact of being allowed to have contact with the child and to be informed about the child's condition generate comfort and feeling of security and trust ${ }^{(16,20)}$. The theoretical assumptions lead the nurse to recognize the importance of the parents in the participation in the care of at risk newborns, but in a situation of emergency, prioritize the technical procedures in detriment to the humanistic attitudes, as evidenced in the following category.
Category: Feeling difficulties in an emergency situation (reasons why)

Some nurses were concerned about the presence of the parents in certain situations, especially in emergencies, and verbalized their preference that the parents are not in the NICU:

[...] only when the situation is an emergency, very urgent, they end up getting very anxious [...] at times we ask them to leave because they end up interfering in a way that would cause us to slightly lose control (D2).

It is a little difficult if the child is in a critical condition and the mother is very anxious [...] because then they question many things $[\ldots]$ sometimes it's a moment that you cannot stop and explain the procedure that you are performing, it makes it difficult (D5).

The results of another study carried out in a NICU showed that the nurses mentioned that, faced with the parents of the newborn, they become tense, they do not feel comfortable in performing invasive procedures on the neonate in a serious condition and they believe that the parents are not prepared to accompany their child in a complex situation. They could clearly distinguish between the situations that allow the presence of the parents, such as changing diapers, handling and others. Although they knew the importance of closeness between them, they did not feel the need of their presence fulltime $^{(7)}$.

It is also important to note in this context the performance of a study that sought to understand the beliefs of nurses regarding the presence of the parents of newborns in high risk neonatal units. The results highlighted that, for this professional, the presence of the parents in certain situations, is configured as a factor that has implications for the development of certain actions by the team and that can interfere with the running of the service(8). Conversely, it was observed that the presence of parents could also be seen from another perspective, which involves the recognition of this presence as therapeutic for the neonates. In this sense, the nurses of the present study expected to perform actions that favor the proximity of the parents and children and they felt responsible for this proximity, as is explained in the next category.

Category: Being the link in the proximity of parents and children (reasons for)

The nurse facilitates the early contact between parents and premature babies, aiming to establish the bond and commitment, bearing in mind that this is a 
gradual process that can take days or weeks of the postnatal period:

[...] we, in some way, try to alleviate, and then it is face to face, talking, and being together, showing that you have not only technical expertise [...], but also have emotional competence [...] we explain what is happening and they see the effective participation of the team [...] they learn to understand that we like what we do concerning the child, respect them, and they will have more confidence in us (D2).

Care based on the comprehension of the other, in the social interaction, sharing the anguish of the parents who have their babies hospitalized in the NICU, is what shows the action of the nurse in the formation of emotional bonds between children and parents ${ }^{(7)}$. The discourses of the NICU nurses show that allowing the parents to stay together with the NB - giving affection, handling, following the child closely - are actions that can help these parents to strengthen the emotional bond with the child:

[...] we have to do all we can do in order to construct this bond between mother and child and it works [...] this action of the nurse I believe is very important [...] we are closest to them, I think it has to come from us, this increase of the bond between mother and baby (D1).

The need for the formation of a bond between the newborn and the family in the NICU is recognized in other studies that emphasize the care to the parents and the participation of the family in the hospital care of the neonates in the neonatalogical services. The long period of hospitalization of the babies and the deprivation of the environment increases the stress of the parents, which may detrimentally affect the establishment of the bond and attachment. The child needs the mother and does not exist alone, therefore the skills and/or difficulties of the parents integrate them into the healthcare in the NICU(11-12,21).

The Experienced Type of the social group "the nurse that experiences the care provided to the newborn faced with the presence of the parents" can be described as those who perceive the needs of parents; have positive expectations regarding the care performed and recognize themselves to be the link between them, helping them to accept and live with a hospitalized child. However, the nurses have difficulties in the care of the newborn in emergency situations when the parents are present in the NICU.

\section{Final considerations}

The results of this study show the importance of the nursing action in the NICU as a factor of parental involvement in the care for the newborn, emphasizing the relationship of care identified and established between the nurse, the newborn and the parents. The comprehension of the experience of nurses directed towards the newborn whose parents are present in the context of the NICU draws attention not only to the importance of maintaining them together with their children, but also to recognizing them as potential subjects that need to be perceived and cared for by the healthcare team. Thus, the comprehension of this experience by the NICU nurse allows us to perceive that, in this practical scenario, unidirectional care - to the neonate - does not exist, but a context of care infant/parents/nurse - that should be considered in the planning and the execution of the care to the newborn. Therefore, from this context of care emanates an emotional relationship that links the triad of subjects described, who exert mutual actions and reactions that permanently reconfigure the scenario of assistance and, therefore, their own relationships. This also explains why the presence of the parents is not wanted by the nurses in situations of emergency, since the reaction that such an event causes allows a reconfiguration of the relationships between the subjects (nurse/parents of the newborns).

The study allows the elucidation that the nurse perceives the presence of the parents in the NICU in a mainly positive way, permanently involving them in the care of the newborn. This denotes the need to think that the apprehension of this experience indicates new directions to consider regarding the care in the NICU, considering all the subjects involved. It is hoped that this study will inspire other studies that can address, from the most diverse perspectives possible, the vision of this context of care. It is also hoped that this study will be echoed in the scenario of the NICU, so that the relationship of care (nurse/neonatal/parents) is permanently considered and reconsidered, seeking a proximity between the subjects and the demands presented by them.

\section{References}

1. Vasconcelos MGL, Leite AM, Scochi CGS. Significados atribuídos à vivência materna como acompanhante do recém-nascido pré-termo e de baixo peso. Rev Bras Saúde Mater Infant. 2006;6(1):47-57.

2. Hendricks-Muñoz KD, Prendergast CC. Barriers to provision of developmental care in the neonatal intensive care unit: neonatal nursing perceptions. Am J Perinatol. 2007;24(2):71-7. 
3. Campos ACS. O significado de ser mãe de um recémnascido sob fototerapia: uma abordagem humanista. [Mestrado]. Fortaleza (CE): Universidade Federal do Ceará, Programa de Pós-Graduação de Enfermagem; 2005.

4. Gaíva MAM, Scochi CGS. A participação da família no cuidado ao prematuro em UTI neonatal. Rev Bras Enferm. 2005;58(4):444-8.

5. Schmitz EM. A enfermagem em Pediatria e Puericultura. São Paulo (SP): Atheneu; 2006.

6. Pires VMMM, Rodrigues VP, Nascimento MAA. Sentidos da integralidade do cuidado na saúde da família. Rev Enferm UERJ. 2010;18(4):622-7.

7. Conz CA, Merighi MAB, Jesus, MCP. Promoting affective attachment at the neonatal intensive care unit: a challenge for nurses. Rev ESC Enferm USP. 2009;43(4):849-55.

8. Rossato-Abéde LM, Angelo M. Beliefs determining the nurse's intention concerning the presence of parents in neonatal intensive care units. Rev. Latino-Am. Enfermagem. 2002;10(1):48-54.

9. Araújo BBM, Rodrigues BMRD. Mothers' experiences and perspectives regarding their premature infant's stay at the Neonatal Intensive Care Unit. Rev Esc Enferm USP. 2010;44(4):865-72.

10. Araújo BBM, Rodrigues BMRD. O alojamento de mães de recém-nascidos prematuros: uma contribuição para a ação da enfermagem. Esc Anna Nery. 2010;14(2):284-92.

11. Guimarães GP, Monticelli M. Attachment formation between parents/pre-term newborns and/or low birth weigth children using the kangaroo mother method: a contribution to nursing. Texto Contexto Enferm. 2007;16(4):626-35.

12. Molina RCM, Fonseca EL, Waidman MAP, Marcon SS. The family's perception of its presence at the pediatric and neonatal intensive care unit. Rev Esc Enferm USP. 2009;43(3):630-8.

13. Schütz A. El problema de la realidad social. Escritos I. 2ed. Buenos Aires (AR): Amorrortu; 2003.

14. Carvalho GM, Merighi MAB, Jesus MCP. The experience of repeated fatherhood during adolescence. Midwifery. 2010;26(4):469-74.

15. Conselho Nacional de Saúde (BR). Resolução n. 196, de 10 de outubro de 1996. Dispõe sobre diretrizes e normas regulamentadoras de pesquisas envolvendo seres humanos. Bioética. 1996;4(2 Supl):15-25.

16. Baker BJ, Mcgrath J. Parent Education: The Cornerstone of Excellent Neonatal Nursing Care. Newborn Infant Nurs Rev. 2011;11(1):6-7.

17. Rolim KMC, Cardoso MVLML. Discourse and practice of care to newborns at risk: reflecting about humanized care. Rev. Latino-Am. Enfermagem. 2006;14(1):85-92. 18. Butter C, Gahin K. Parents' perceptions of staff competency on a neonatal intensive care unit. J Clin Nurs. 2003;12:752-61.

19. Gooding JS, Cooper LG, Blaine AI, Franck LS, Howse JL, Berns SD. Family Support and Family-Centered Care in the Neonatal Intensive Care Unit: Origins, Advances, Impact. Semin Perinatol. 2011;35(1):20-8.

20. Barbosa ECU, Rodrigues BMRD. Humanização nas relações com a família: um desafio para a enfermagem em UTI pediátrica. Acta Scientiarum Health Sci. 2004;1(26):205-12.

21. Pinheiro EM, Silva MJP, Ângelo M, Ribeiro CA. The meaning of interaction between nursing professionals and newborns/families in a hospital setting. Rev. LatinoAm. Enfermagem. 2008; 16(6):1012-8.
Received: Nov. $9^{\text {th }} 2010$ Accepted: May 30 2011 